\title{
Female expatriates' motivations and challenges: the case of oil and gas
}

\author{
Type of submission: Case study
}

\begin{abstract}
Purpose

This case study is designed as a teaching exercise and to highlight key issues for organisations expatriating women within masculine industry sectors and/or into challenging international environments.

\section{Design/methodology/approach}

This case study draws together key published findings relating to women's expatriation in the oil and gas exploration and production sector. It demonstrates a triangulated research design, drawing upon organisational policy from two oil and gas firms, semi-structured interviews with 14 Human Resource professionals and 26 female expatriates, as well as from 71 female assignees' questionnaire responses.
\end{abstract}

\section{Findings}

Career and financial drivers underpin women's motivations for accepting organisationallyassigned expatriation. Women expatriates engage in satisficing and career compromise. The main challenges women face in masculine industries include: access to expatriate roles due to limited female networks; family concerns; managing working time and work-life balance; and coping with loneliness.

\section{Research limitations/implications}

The oil and gas case findings are based on a cross-sectional research design. The majority of female expatriates undertook long-term assignments; limited numbers engaged in flexpatriation. 


\section{Practical implications}

While organisational policy supporting expatriation does not usually address gendered expatriate concerns specifically, inclusion of interventions that are identified by women as helpful to their expatriate participation can assist in increasing expatriate gender diversity.

\section{Originality/value}

This oil and gas research case brings together and presents a summary of the motivations, problems and challenges faced by women in male-dominated expatriate environments, together with relevant theoretical approaches and organisational interventions to help us understand and increase expatriate gender diversity. 


\section{Female expatriates' motivations and challenges: the case of oil and gas}

\section{Women's expatriation: introduction to the case context}

The extant literature suggests that career and skills development, role autonomy, professional challenge and living in a foreign country all factor in the expatriation decision-making process and help to make it an attractive proposition (Andersen and Scheuer, 2004; Bonache, 2005; Doherty et al., 2011; Suutari et al., 2012). International experience is considered a precursor to leadership positions (Orser and Leck, 2010) and a highly 'portable asset', opening up opportunities external to expatriates' sending organisations (Haslberger and Brewster, 2009). The deployment of expatriates is also crucial to employing organisations building a global talent base (McDonnell et al., 2017).

Diversity is well-known to provide significant business advantages (Department for Business, Innovation and Skills, 2013). Yet, around three-quarters of expatriates assigned by their employing organisations to work abroad are men (Brookfield, 2016). The low representation of female expatriates is thus disadvantageous not only to women's careers but also to organisations which could otherwise benefit from women's successful global management and expatriate track records (Cole and McNulty, 2011; Harrison and Michailova, 2012; Tung, 2004). As such, understanding potential organisational action to increase expatriate gender diversity in a case context is of paramount importance to business scholars and the academics who teach them, employers, and women wishing to pursue international careers.

This case takes women's organisationally-assigned expatriation in two oil and gas exploration and production firms as its focus for a learning exercise. It aims to bring together evidence on women's motivations for undertaking a variety of assignments with the problems and challenges that they face when expatriating in highly male-dominated workplace 
environments. Industries such as oil and gas have traditionally posted expatriates into challenging geographical domains, such as climatically harsh, disease-prevalent, and insecure, dangerous places, in search of mineral wealth (Whitson, 2013). This has resulted in a male-dominated expatriate workforce (ORC Worldwide, 2007; Shortland, 2014a). How female expatriation can be facilitated in such environments will be of value not only to oil and gas as this industry expands geographically to exploit new reserves such as shale gas (Sapsted, 2013) but also to other industries, as they increasingly extend their reach into newly emerging economies (Holmes, 2013). Hence, the lessons learnt from oil and gas can be applied not only in other male-dominated sectors (such as engineering and mining) which are also very large users of expatriates (ORC Worldwide, 2007; Richardson et al., 2014), but also across a wider spectrum of industry sectors as organisations expand their operations into less traditional, more remote, and hardship expatriate destinations.

Understanding women's motivations to expatriate in masculine environments given the potential difficulties and discouragement they may face can provide critical insights into how women's expatriate access can be widened. This case thus draws upon relevant theoretical perspectives and women's experiences to present a teaching aid exemplifying the interventions that employers can use to facilitate expatriate gender diversity. It begins by

outlining theoretical concepts and empirical evidence drawn from the extant literature before outlining the case method and its principal findings. Implications for theory and practice, research limitations and a call for further research are presented before conclusions are drawn.

\section{Theoretical and empirical perspectives}

A wide range of theoretical perspectives can be applied to explain and predict women's expatriation (Shortland, 2009; Shortland and Altman, 2011). For example, Mainiero and 
Sullivan's (2005) 'kaleidoscope' career theory predicts that relational demands during women's child-rearing years should lead to them to reject career-enhancing expatriation. Alternatively, women may attempt to maintain and maximise the outcomes from both a career and a family life through satisficing (Crompton and Harris, 1998a, 1998b). But expatriates work long hours and these intrude into their family lives (Fischlmayr and Kollinger, 2010), suggesting that satisficing may not be viable. Indeed, Corby and Stanworth (2009) suggest that women engage in career compromise. This means that women may be predicted to undertake sub-optimal expatriate positions in relation to career outcomes and put their families first.

Dual careers and the role of the family in women's career choices have been highlighted for many years as major factors hindering a couple's expatriate participation (Harvey, 1997; Mäkelä et al., 2011; Selmer and Leung, 2003a; Välimäki et al., 2009). Alternative assignment types may provide a means of maintaining two careers. Flexpatriation refers to short-term, commuter, frequent flier and rotation style assignments (Festing et al., 2013). These forms of international mobility are typically carried out on single status. Women do engage in these types of expatriation, thereby gaining international experience, but this choice can lead to family life compromise when women put their careers first (Mayerhofer et al., 2004).

Harvey (1998) proposed that male family power dominates and thus the male career is prioritised over that of the female career. As demographics have changed and more nontraditional expatriates are deployed, including executive women who hold the lead career in status-reversal marriages (McNulty, 2014a; Permits Foundation, 2009), this has challenged the theoretical notion of male family power (Shortland, 2009). Spouse-related problems have, for many years, been reported as greater particularly when men have to adjust to the foreign environment (Cole, 2011; Punnett et al., 1992), to being secondary breadwinners (Harvey and 
Wiese, 1998) or to when they face unemployment (Permits Foundation, 2009). It is especially problematic when male spouses face isolation (Cole, 2012) and negative stereotyping in the host country, for example when taking on a househusband rather than an income-earning role (Välimäki et al., 2009). It is also notable that corporate career support is focused to a greater extent on female trailing spouses than on trailing males (Selmer and Leung, 2003a). Thus, women in dual career couples potentially face greater barriers to expatriation than men, unless employers recognise and respond to the different demands of the new expatriate dual career generations (Permits Foundation, 2009).

Self-initiating one's own expatriation gives control over the decision to the individual; it is notable that around half of self-initiated expatriates are women (Tharenou, 2014). Organisationally-assigned expatriation is controlled by the employer, limiting the choices available to those relocating. Constraints include organisational decision-making on the nature of the assignment and timing of the deployment (Tharenou, 2009). Women are further hindered by lack of fair treatment in selection practice (Tharenou, 2010). This suggests that women in the corporate world cannot "“have it all', that is, a successful career, a good personal relationship and children" (Linehan and Walsh, 1999, p. 268). To explore this further, satisficing (Crompton and Harris, 1998a, 1998b) and career compromise (Corby and Stanworth, 2009) provide helpful theoretical frames, particularly when applied to women expatriating mid-career, often during the 'balance' stage of their 'kaleidoscope careers' (Mainiero and Sullivan, 2005).

While financial rewards are recognised as not being the main driver behind expatriation (McNulty, 2014b) they are, nonetheless, typically comprehensive and often quite generous (Kroeck and Von Glinow, 2015). This can be explained by the compensating differentials model (Rosen, 1986) which indicates that additional income is needed to encourage workers to accept jobs that are undesirable relative to others. Despite its career 
benefits, expatriation is somewhat unattractive as a result of potential family separation and disruption associated with moving, living and working abroad. Additional reward (a compensating differential) is therefore required to offset these negative issues.

According Anker's (2001) gendered explanation of compensating differentials, women are expected to seek good fringe benefits and working conditions, aligned to their homemaker status (Crompton, 1999). It would thus be expected that female expatriates would place high value on organisational support for their domestic role, seeking expatriate benefits that support their homemaker and child bearing/raising family duties (such as childcare) rather than financial betterment. The 'family-friendly' nature of the expatriate reward package (for example, addressing issues such as support for children's education) therefore may influence women's decisions to expatriate (Shortland and Perkins, 2016).

Reviews of the extant literature indicate that women across industries share comparable career motivations in pursuing expatriate opportunities. They also face a number of similar challenges in undertaking expatriation. These include perceptions of host-country prejudice, work/family life conflict, and greater difficulties than men at each stage of the expatriate cycle including home country selection bias and less access to support mechanisms such as networks while in-post and on repatriation (Hutchings and Michailova, 2014; Shortland, 2014b; Shortland and Altman, 2011). However, the literature on female expatriation examined in relation to specific industries is limited. ORC Worldwide (2007) records women's expatriate participation as ranging from 30\% in non-profit/charity and governmental organisations and $27 \%$ in legal, consulting and professional services, falling to just $6 \%$ in construction and engineering. Masculine sectors such as mining also employ a low percentage of female expatriates; with women's distinctiveness in the expatriate context summed up neatly in the title of Richardson et al.'s (2014) paper “They always look at you a bit oddly". The differences in female expatriate participation figures suggest that there are 
challenges specific to particular industries that require investigation if expatriate gender diversity is to increase.

Women comprise only around 7-10\% of expatriates in the oil and gas industry (ORC Worldwide, 2007; Shortland, 2014a). At first sight, this sector might therefore appear to be an unusual choice for case consideration of actions to increase female expatriation given that women's share of expatriate roles within it is well below the all-industry $25 \%$ female participation figure (Brookfield, 2016). To understand the significance of this sector and the benefits of conducting research within it, it is helpful to begin by understanding the context as to why women's oil and gas expatriate participation is so low. Expatriation takes place 'upstream' in exploration and drilling operations (Markus, 2015) and the roles that expatriates perform (primarily engineering and field geology and geophysics roles) are maledominated (Shortland, 2009). But oil and gas firms employ relatively high proportions of their workforce as expatriates. For example, Air Inc. (2016) reports that in the oil and gas sector $6.4 \%$ of the workforce are expatriates, compared with the more typical expatriate representation of $1.8 \%$ of a multinational company's workforce (Permits Foundation, 2012). This means that because oil and gas employ large expatriate volumes, the low female percentage share of these roles translates into relatively high numbers of women holding expatriate positions - so there is much that we can learn from them. This leads us to consider why women undertake expatriation, the particular challenges that they face, and how these are overcome. The following section therefore examines these issues in a case context in the oil and gas sector set within relevant literature in the field.

\section{The oil and gas case: method}

This case research drew upon two oil and gas firms, North American and Western European headquartered (Company A and Company B respectively), employing a total of around 
18,000 people world-wide, which took part in a major research project on female expatriation. Company A's expatriates comprised 3\% of its workforce and $8 \%$ of this population were female (27 women); company B's expatriates comprised $10 \%$ of its workforce and $11 \%$ of this population were female (66 women). The female expatriates represented a total of 23 home and host countries on all continents. The research method involved:

- the collection and analysis of each firm's Human Resource (HR) policies relating to expatriation;

- semi-structured interviews with 14 HR professionals (four in Company A and 10 in Company B) responsible for policy design and its implementation;

- an e-mail questionnaire sent to all of the 93 current women expatriates and completed by $76 \%$ of those contacted ( 71 female expatriates: 51 on long-term assignments, 12 on short-term assignments, five on rotational assignments and three undertaking extended expatriate transfers); and

- semi-structured interviews with 26 of the respondents selected to ensure appropriate representation by company, host location, assignment length and pattern, previous expatriate experience, and family status.

Following analysis of the firms' policy documentation, interviews were conducted with the HR professionals to establish how they believed that policy design and implementation supported women's expatriate participation. The questionnaire sought data on the expatriates' profiles. It also sought information as part of the wider research project on the importance that female expatriates attached to various organisational policy issues, including selection, training, career development, working time and reward. It did not specifically address expatriate motivations and challenges in detail - these were addressed in depth via the qualitative research. Interviews with the female assignees (conducted separately 
from those of HR) explored the extent to which organisational policy and how it was implemented in practice by the HR professionals addressed any challenges and perceived obstacles and thereby facilitated their international mobility. The interviews were transcribed and analysed thematically using NVivo 8. Confidentiality was maintained with pseudonyms used.

\section{Findings and analysis}

\section{Assignee profile}

The traditional expatriate profile comprising married males and single females (Selmer and Leung, 2003b) has experienced some change in recent years. According to Brookfield (2016), married/partnered men comprise $49 \%$ and single men $22 \%$ of the assignee population industry-wide; married/partnered women comprise $19 \%$ and single women $10 \%$ of assignees. In the oil and gas case, $63 \%$ of the female expatriates were married or partnered; $37 \%$ were single/divorced/widowed. However, only $46 \%$ of the female expatriates were accompanied while 54\% went solo; $45 \%$ took their children with them. For comparison, Brookfield (2014) reports that industry-wide, $78 \%$ of all expatriates are accompanied by their spouse/partner while $22 \%$ go solo; $47 \%$ take children with them on assignment. The oil and gas case data suggest that the nature of expatriation in this industry is either not conducive to women being accompanied by their spouses/partners and/or that women can undertake single status expatriation while maintaining relationships at home. The following section examines the oil and gas case data and sets these within the context of the extant literature to identify new understandings.

\section{Women's expatriate motivations}


Career development: International assignments are generally known to provide career as well as social capital (Dickmann and Baruch, 2011), developing individuals' capabilities of 'knowing how', 'knowing why' and of 'knowing whom' (Dickmann and Doherty, 2010). Expatriation also leads to personal, professional and leadership development, promoting career advancement external to the sending organisation (Dickmann et al., 2008). Specifically in relation to women's motivations to undertake expatriation, evidence is similar - it suggests that career potential is the major driver (Shortland, 2016). Competency development is also an important aspect in their participation decision-making (Mayerhofer et al., 2004); women report expatriation improves their knowing how, why and whom career competencies, thereby helping to leverage future employment advancement opportunities (Richardson et al., 2014).

In the oil and gas case, in both the survey and in the interviews, the female assignees reported significant career development advantages from undertaking expatriation. In addition to gaining professional, international, personal and cultural experiences, the female expatriates cited learning opportunities, skills development, challenge and autonomy, higher levels of responsibility and work variety as factors that added career value. As one survey respondent summed up:

"The potential to enhance my career through assignment acceptance, to work in another country, another company, different culture, new challenges ... it's a really good opportunity for my career and development.” Tina, Western Europe

HR representatives also confirmed the career benefits of expatriation:

"... quite often, that is the case, the skills they have learned while on assignment, when they come back, quite often it can be into a more senior role." Alexis, $H R$ representative 
Financial reward: Financial rewards also motivate individuals to take an international assignment - although the literature points out that these are not the primary drivers (Dickmann et al., 2008). Expatriates usually receive home-based compensation and benefits arrangements (the 'balance sheet' system) (Sims and Schraeder, 2005). This approach operates on the basis that assignees are no better or worse off as a result of undertaking their assignment (Perkins et al., 2016). Elements include: remuneration, including base salary and compensatory premiums for hardship and mobility; allowances to address assignees'

additional costs (such as cost of living, housing/utilities, children's education and travel); and other benefits and insurances (such as car provision, tax/visa assistance, medical/healthcare) (Kroeck and Von Glinow, 2015). These additional compensatory payments can make expatriation financially rewarding (Perkins et al., 2016).

Oil and gas is well-known for its use of the balance sheet in rewarding expatriates (Chesters, 1998). International assignment policy analysis in the oil and gas case research confirmed that both firms used this system with generous allowances paid. Assignments were seen as financially attractive by the HR professionals interviewed:

“... (they) are quite comfortable ... I think against a lot of companies they are on a very good ticket." John, HR representative

However, for the female assignees interviewed, the financial benefits while welcomed were frequently viewed as providing some compensation when their own or their partner's career expectations were not addressed:

"For me it is entirely career-driven and it is for my partner as well. Given that I am here and it is not a career-enhancing move, it is sideways at best, I do repeat to myself quite regularly at least there is some money! When I get bored at work! So is primarily career. Or at least it would be if it was a career move!" Rhoda, Australasia 
“We wouldn't have moved to (North America) ... if there hadn't been an expat package associated with that ... it was a great career move for me, but it was very difficult from (husband's) career perspective, and the thing that made it okay, it was the fact that we had a little bit of money put in our pockets, that our lifestyle changed as a result of it." Di, East Asia

Policy analysis indicated that newly-emerging economies and remote/hostile locations attracted particularly generous allowances to address security, health and access issues. These payments were considered highly motivational by both the HR representatives and the female assignees. However, as the HR representatives and assignees interviewed noted, if women rejected a location on health, security and lifestyle grounds (for instance, if spouse employment and children's education were unsuitable), additional financial inducements would not overturn their decision to reject expatriation. The high value women placed on the location of expatriate housing, maintaining family relationships and support for their children in their expatriation participation decision was confirmed by the assignees interviewed, providing some support for Anker's (2001) prediction that women 'prefer' fringe benefits that maintain their family life, although as recognised by both HR and the interviewees, women also look to the financial rewards contained within expatriation policy.

\section{Problems and challenges}

Networks: As Altman and Shortland (2008) state in their summary of the female expatriate extant literature, bias in organisational selection has been documented since the earliest articles exploring female expatriation (Adler, 1984). Shortland and Altman (2011) highlight a number of issues as contributory explanations including: stereotyping of women as being less mobile than men (Moore, 2002); insufficiently rigorous, informal and haphazard selection processes (Linehan and Scullion 2001; Linehan et al., 2001); and women's lack of strong 
relationships with their supervisors (Varma and Stroh, 2001). In addition, home country managers' perceptions of (unfounded) host country prejudice against women expatriates (Paik and Vance, 2002) also play a role in reducing women's chances of being selected. Harris (2002) finds that open and transparent approaches to selection result in greater levels of female expatriate participation while closed and informal selection systems create (albeit unintended) gender bias. This is particularly disadvantageous to women because the expatriate selection process relies heavily on known contacts, for example, via networks and mentors (Linehan et al., 2001). In the oil and gas research, the female assignees interviewed said that maintaining networks played a very important role in them gaining expatriate roles. They also reported that networks were valuable in helping them: gain an understanding of the country and lifestyle; find advice on dual career and family issues; gain social support (especially for singles); and manage cultural considerations which affected their reception and acceptance.

Role models: A lack of female role models is identified as one of the greatest barriers to women's advancement in management (Catalyst, 2003). In the oil and gas research women expatriates were in the minority. Yet, although the HR representatives believed in the inspirational value of female expatriate role models in encouraging women to apply for expatriate roles, the women expatriates interviewed did not perceive them as particularly important to their expatriate participation. They explained this as being due to their relative paucity; not seeing themselves as assignee role models; and because of the lack of organisational support for role models who could assist others to consider expatriate careers.

Children: Family responsibilities are usually reported as barriers to women's expatriation in the extant literature (Hutchings et al., 2010; Tharenou, 2008; Tzeng, 2006). 'Kaleidoscope' 
career theory (Mainiero and Sullivan, 2005) predicts that women would not undertake expatriation during their child-rearing years. Yet, in the oil and gas case research, having children prompted some women to expatriate. In their home countries, they reported long commutes and expensive childcare precluded them from combining motherhood with continuing in full-time work. By comparison, an expatriate role enabled them to work fulltime:

"I couldn't continue, I was working part-time ... and continually had pressure put on to go full-time, because people perceive, you know, that things are going to be happening that need actioning and typically it will happen on the day that you're not there. I think that (undertaking expatriation) is a reflection of our personal circumstances ... because we've got three children of school age ....and it is definitely an advantage ... you are seen to have done the international piece." Izzy, Caribbean The mothers interviewed also reported that in emerging economies such as East Asia, the Caribbean and North Africa, they were able to hold full-time expatriate positions because they were provided with housing close to the workplace and had access to low cost, high quality childcare:

"I definitely need to live near the office, and I also need good childcare or support so that as she grows older and goes to school, she obviously wouldn't need the childcare but she would need someone to be available for her." Una, North Africa "I have a live-in maid, who deals with all the domestic chores and helps me to look after the children ... having domestic help is a big, big bonus for me and it makes life out here so much easier than living in the (home country) with my children and the costs of having domestic help are really low here." Wanda, East Asia By attempting to maintain and maximise the outcomes from both a career and a family life, the women demonstrated 'satisficing' behaviour (Crompton and Harris, 1998a, 
1998b). However, in the oil and gas research, the locations which provided affordable/high quality childcare were not considered by the assignees interviewed to be the most careerenhancing, suggesting that the female expatriates compromised their careers when putting their children first (Corby and Stanworth, 2009).

Dual careers: The literature suggests that dual careers act as a barrier to women's expatriation (Permits Foundation, 2012) as women are not usually the primary income earner in the family (Harvey, 1998). The extant literature proposes that short-term assignments enable women to balance expatriation with such considerations as dual careers (Demel and Mayrhofer, 2010). It also indicates likely positive outcomes for assignment success and family life via commuter assignments (Meyskens et al., 2009). Short-term, commuter and rotational assignments in the oil and gas industry were undertaken on single status, enabling women to expatriate leaving their family at home and, as such, these assignment types were used to address dual career barriers to international mobility. Yet, the female expatriates surveyed and interviewed in the oil and gas case research were not keen to undertake such disruptive flexpatriation. It was notable that women sought assignment types that provided the greatest levels of stability and work-family balance. Thus, the majority opted for longterm assignments underscoring their efforts to satisfice (Crompton and Harris, 1998a, 1998b).

We know that men and women undertaking unaccompanied mobility experience work-family conflict (Mäkelä and Suutari, 2011) and that frequent international travel causes stress (Welch et al., 2007). Women's participation in alternative assignment patterns is not identified in great detail in the literature but, from the limited research undertaken to date on women's flexpatriation, we know that women give up such assignment types to address family responsibilities more readily than men (Mayerhofer et al., 2004). As flexpatriation 
arrangements are becoming more prevalent (Mayerhofer et al., 2010; Silbiger and Pines, 2014), these are likely to have a detrimental effect on women's expatriation.

Working time and work-life balance: The literature reports long working hours associated with expatriation (Fischmayr and Kollinger, 2010). The overlap between expatriates' private and public lives is greater for expatriates than for non-mobile employees (Hearn et al., 2008). The tension between work and family life is also greater for expatriates, especially when duties involve working across time zones and high volumes of international travel (Shortland and Cummins, 2007). Policy communication is generally less satisfactory to expatriates than home country-based employees (Bonache, 2005) and hence expatriates report limited awareness of employer policy addressing flexible hours and work-life balance (Shortland and Cummins, 2007). Thus, expatriates tend to experience high work interference with the family life (Fischlmayr and Kollinger, 2010). Harris (2004) reports that women expatriates in particular experience stress due to overlap of work and family roles. Nonetheless, expatriates' working hours can have positive outcomes for performance management and career progression (Shortland, 2015a).

In the oil and gas research, the HR professionals reported that expatriates worked long hours. Despite this, the survey data suggested that working time and work-life balance associated with expatriate roles did not appear to affect women's willingness to expatriate negatively. This was confirmed by the female assignees interviewed. Working longer than contractual hours was accepted as part of the expatriate role:

“I prioritise work ... I'm very passionate about my job. But certainly there ... is just an overriding expectation that you will do the hours. That is just a given." Linda, Australasia 
Nonetheless, the assignees interviewed spoke of ways in which they had taken steps to strike a good work-life balance. They reported making use of unofficial flexible work arrangements, enabling them to fulfil family obligations while undertaking career-enhancing and highly-paid expatriation:

“...we had a quiet arrangement ... we organised a system whereby three ... were always on and three were off. So you couldn't really leave town, and if you had things to do then you had to come in, so it was never that official. So I would say you probably got 10 or 12 Fridays (off) in the year." Val, Caribbean

The assignees interviewed did not currently view their working hours as having a detrimental effect on their work-life balance. However, some expressed concern over undertaking future higher graded roles which they feared might prove too onerous in terms of maintaining an appropriate work-life balance:

"I was on that track and I was doing very well, and I was very ambitious, and I would chase it. But I fast realised that if I got there, I would have to work my ass off ... the sacrifice that I would personally feel that I needed to do to be a proper (high grade) and be respected at the level and meet my standards, and my standards are pretty high ... I didn't want to work that hard. I worked hard enough as it was." Milly, Central Asia

This potentially indicates that women may not seek promotion or high level expatriate roles, compromising their careers in favour of their family lives (Corby and Stanworth, 2009), if they perceive damaging work-life balance implications.

Hardship locations: Challenging working conditions in isolated and hostile locations, a masculine ethos and lifestyle in expatriate camps, combined with lengthy family separation, make single status hardship location assignments unattractive to the majority of women 
(Verma, 2008). Camp environments or compound living result in work and social lives inextricably intertwined, creating 'in-groups' (Lauring and Selmer, 2009). Aligned with Verma's (2008) research, women expatriates interviewed in the oil and gas firms reported that they were confined to camp, while their male colleagues had the freedom to explore outside the worksite. Being confined as a result of cultural and security considerations in some cases led to exclusion from male camaraderie, and sometimes even harassment, resulting in women's social isolation and loneliness.

To combat loneliness, unaccompanied women frequently elect to work long hours and at weekends (Caligiuri and Lazarova, 2002). Solos also undertake educational courses for career development and to fill their spare time (Mendenhall and Stahl, 2000) and cook for friends, rather than eating in the camp canteen's male space (Gordon, 2008). The solo women assignees interviewed in the oil and gas research adopted similar strategies to those reported in the literature and, in addition, facilitated by their HR contacts, they volunteered to provide guidance and support to female expatriate newcomers and to mentor and coach local women employees. In so-doing they were able to build strong female social relationships.

\section{Discussion: implications for research and practice}

There is a wide range of theoretical perspectives used within the extant literature to explain women's expatriate participation. Given this patchwork, there is a need to focus on theories with considerable promise to extend theory building (Shortland and Altman, 2011). From the oil and gas case, women did appear to satisfice (Crompton and Harris, 1998a, 1998b) to maximise as far as possible their careers and family lives, but they did compromise their careers in favour of their families when necessary (Corby and Stanworth, 2009). The oil and gas research also suggested that refinement of theory is needed to reflect women's expatriation. It showed that theoretical perspectives such as women's non-linear 
'kaleidoscope' careers (Mainiero and Sullivan, 2005) and compensating differentials as applied to women's work (Anker, 2001) applied in domestic home country settings did not necessarily fully translate to apply to women's international careers. Our knowledge of women's expatriate geographies and how these might influence theory building is also limited. Hence, theory needs to be tested in new domains as female expatriation extends beyond traditional Western sending and receiving destinations (Shortland and Altman, 2011).

Women's expatriate participation varies by industry, yet we know relatively little about the factors that influence this. We do know though that it can be isolating and lonely for women expatriating in primary sector industries, such as mineral extraction, where the workplace has a gendered setting (such as a remote camp or compound). Typically, men are the expatriates; compound life caters for female spouses (Lauring and Selmer, 2009). In remote or dangerous areas, besides there being very few other women in the workspace, the social and living areas are also male-dominated because expatriates generally go on assignment minus their families. It may be unsafe or unacceptable for women to venture beyond the camp/compound boundary (Shortland, 2015b). Such male-dominated environments are less frequently experienced in secondary and tertiary, manufacturing and service industries.

As the oil and gas research demonstrated, expatriating in a masculine sector presented particular challenges to women. The expatriate selection process is the starting point for these and is thus the critical hurdle that women must overcome. This may require organisations to employ particular strategies to signal to women that their participation is encouraged, if employers are to increase expatriate gender diversity in male-dominated environments. Some suggestions are given below.

Organisational HR policy typically does not differentiate between men and women in terms of international rewards, benefits and support services on assignment. That said, 
employer provision of housing close to the expatriate workplace can assist women to combine expatriate work with childcare. Payments to support children's education are a valuable facilitator of mothers' expatriation. When women expatriate solo, employer support to help them build social lives and maintain family ties can be helpful. Provision of information on issues that women report as being of particular importance (such as salary uplifts, housing, and children's health, welfare and education) can also help to support women's decisions to expatriate.

Organisational support for role models and networking links/strategies tends to be limited but, while so few women are seen to hold expatriate positions in masculine sectors and opportunities are gained via informal male networks, women will continue to hold only a minority expatriate share. Active intervention by employers is needed. However, care is required in this endeavour. Women's networks, while helpful, might unintentionally reinforce male preserves. Accountability is also required within organisations to promote and support expatriate gender diversity.

A further issue concerns the types of assignments available; women prefer long-term, accompanied assignments. Employers wishing to extend expatriate gender diversity need to bear this in mind; especially as greater organisational emphasis is being placed on short-term assignments and other forms of unaccompanied mobility (Silbiger and Pines, 2014).

\section{Future research directions}

Current studies of women's expatriation are primarily small scale and cross-sectional in design. As such, generalisation becomes difficult. Future research will benefit from larger scale studies (both quantitative and qualitative), across a range of locations and sectors, to gain a clearer picture of women's motivations and concerns. From these, organisational action can be tailored more effectively to support increasing gender diversity in expatriation 
across different geographies and industries. A longitudinal focus is also critical so that we can attempt to establish trends. For example, without longitudinal studies, we are unable to determine how their current assignments and/or different lengths and patterns of international mobility specifically affect women's career, reward and family outcomes in the medium and longer term. We also need to know far more about the women themselves - hearing more women's voices if we are to gain a fuller understanding of women's expatriation.

\section{Conclusion}

Women undertake expatriation to further their careers, although family and financial issues also act as drivers to international mobility. Women's expatriation can be theorised using satisficing as women use strategies to maximise career and family advantages from expatriation. However, they also engage in career compromise when necessary to achieve an acceptable career and family balance. Employer interventions to increase expatriate gender diversity need to include consideration of assignment lengths and patterns, as well as the content of organisational policy that supports international mobility. Further research is needed across a variety of industry sectors, and over time, to refine both our theoretical and practical understanding of the constraints that hinder women's participation in expatriation from reaching the same level as men's.

\section{References}

Adler, N.J. (1984), "Expecting international success: female managers overseas", Columbia Journal of World Business, Vol. 19 No. 3, pp. 79-85.

Air Inc. (2016), 2016 Mobility Outlook Survey, Air Inc., Cambridge, MA. 
Altman, Y. and Shortland, S. (2008), "Women and international assignments: taking stock - a 25 year review”, Human Resource Management, Vol. 47 No. 2, pp. 199-216.

Andersen, T. and Scheuer, S. (2004), “Attitudes toward foreign assignments among Danish economists", Thunderbird International Business Review, Vol. 46 No. 6, pp. 725-741.

Anker, R. (2001), “Theories of occupational segregation by sex: an overview”, in Loutfi, M.F. (Ed.), Women, Gender and Work: What is Equality and How Do We Get There?, International Labour Organization, Geneva, pp. 129-155.

Bonache, J. (2005), "Job satisfaction among expatriates, repatriates and domestic employees: the perceived impact of international assignments on work-related variables", Personnel Review, Vol. 34 No. 1, pp. 110-124.

Brookfield (2014), Global Relocation Trends: 2014 Survey Report, Brookfield Global Relocation Services, Chicago, IL.

Brookfield (2016), Global Mobility Trends Survey, Brookfield Global Relocation Services, Chicago, IL.

Caligiuri, P. and Lazarova, M. (2002), “A model for the influence of social interaction and social support on female expatriates' cross-cultural adjustment", The International Journal of Human Resource Management, Vol. 13 No. 5, pp. 761-772. 
Catalyst. (2003), "Women in leadership: comparing European and U.S. women executives", available at: http://lenus.ie/hse/bitstream/10147/42684/1/2067.pdf (accessed 4 April 2013).

Chesters, A. (1998), "Reward in an international context", Journal of Professional HRM, Vol. 10 January, pp. 24-30.

Cole, N. (2011), "Managing global talent: solving the spousal adjustment problem", The International Journal of Human Resource Management", Vol. 22 No.7, pp. 1504-1530.

Cole, N. (2012), "Expatriate accompanying partners: the males speak", Asia Pacific Journal of Human Resources", Vol. 50 No.3, pp. 308-326.

Cole, N. and McNulty, Y. (2011), "Why do female expatriates "fit-in" better than males? An analysis of self-transcendence and socio-cultural adjustment", Cross Cultural Management: An International Journal, Vol. 18 No. 2, pp.144-164.

Corby, S. and Stanworth, C. (2009), “A price worth paying? Women and work - choice, constraint or satisficing”, Equal Opportunities International, Vol. 28 No. 2, pp. 162-178.

Crompton, R. (1999), "The decline of the male breadwinner: explanations and interpretations", in Crompton, R. (Ed.), Restructuring Gender Relations and Employment: The Decline of the Male Breadwinner, Oxford University Press, Oxford, pp. 1-25.

Crompton, R. and Harris, F. (1998a), “Explaining women's employment patterns: 'orientations to work' revisited”, British Journal of Sociology, Vol. 49 No. 1, pp, 118-136. 
Crompton, R. and Harris, F. (1998b), "Gender relations and employment: the impact of occupation”, Work, Employment \& Society, Vol. 12 No. 2, pp. 297-315.

Demel, B. and Mayrhofer, W. (2010), "Frequent business travellers across Europe: career aspirations and implications", Thunderbird International Business Review, Vol. 52 No. 4, pp. 301-311.

Department for Business, Innovation and Skills (2013), "The business case for equality and diversity”, available at: https://www.gov.uk/government/organisations/department-forbusiness-innovation-skills (accessed 3 February 2017).

Dickmann, M. and Baruch, Y. (2011), Global Careers, Routledge, Abingdon.

Dickmann, M., Doherty, N., Mills, T. and Brewster, C. (2008), "Why do they go? Individual and corporate perspectives on the factors influencing the decision to accept an international assignment", The International Journal of Human Resource Management", Vol. 19 No.4, pp. $731-751$.

Dickmann, M. and Doherty, N. (2010), "Exploring organizational and individual career goals, interactions, and outcomes of developmental international assignments", Thunderbird International Business Review, Vol. 52 No. 4, pp. 313-324. 
Doherty, N., Dickmann, M. and Mills, T. (2011), "Exploring the motives of company-backed and self-initiated expatriates", The International Journal of Human Resource Management, Vol. 22 No. 3, pp. 595-611.

Festing, M., Budhwar, P.S., Cascio, W., Dowling, P.J. and Scullion H. (2013), “Current issues in international HRM: alternative forms of assignments, careers and talent management in a global context”, Zeitschrift für Personalforschung, Vol. 27 No. 3, pp. 161166.

Fischlmayr, I.C. and Kollinger, I. (2010), "Work-life balance - a neglected issue among Austrian female expatriates", The International Journal of Human Resource Management, Vol. 21 No. 4, pp. 455-487.

Gordon, L. (2008), “The Shell ladies project: making and remaking home”, in Coles, A. and Fechter, A.-M. (Eds.), Gender and Family among Transnational Professionals, Routledge, London, pp. 21-39.

Harris, H. (2002), “Think international manager, think male: why are women not selected for international management assignments?", Thunderbird International Business Review, Vol. 44 No. 2, pp. 175-203.

Harris, H. (2004), “Global careers. Work-life issues and the adjustment of women international managers”, Journal of Management Development, Vol. 23 No. 9, pp. 818-832.

Harrison, E.C. and Michailova, S. (2012), "Working in the Middle East: Western female 
expatriates' experiences in the United Arab Emirates", The International Journal of Human Resource Management, Vol. 23 No. 4, pp. 625-644.

Harvey, M. (1997), “Dual-career expatriates: expectations, adjustment and satisfaction with international relocation”, Journal of International Business Studies, Vol. 28 No. 3, pp. 627658.

Harvey, M. (1998), "Dual career couples during international relocation: the trailing spouse", The International Journal of Human Resource Management, Vol. 9 No. 2, pp. 309-331.

Harvey, M. and Wiese, D. (1998), “The dual-career couple: female expatriates and male trailing spouses”, Thunderbird International Business Review, Vol. 40 No. 4, pp. 359-388.

Haslberger, A. and Brewster, C. (2009), "Capital gains: expatriate adjustment and the psychological contract in international careers", Human Resource Management, Vol. 48 No. 3, pp. 379-397.

Hearn, J., Jyrkinen, M., Piekkari, R. and Oinonen, E. (2008), ““Women home and away”: transnational managerial work and gender relations", Journal of Business Ethics, Vol. 83 No. 1, pp. $41-54$.

Holmes, R. (2013), "Fuelling the talent pipeline: energising the oil and gas sector", Re:Locate, Autumn, pp. 16-18. 
Hutchings, K., Metcalfe, B.D. and Cooper, B.K. (2010), "Exploring Arab Middle Eastern women's perceptions of barriers to, and facilitators of, international management opportunities", The International Journal of Human Resource Management, Vol. 21 No. 1, pp. 61-83.

Hutchings, K. and Michailova, S. (2014), "Women in international management: reviewing past trends and identifying emerging and future issues", in Hutchings K. and Michailova, S. (Eds.), Research Handbook on Women in International Management, Edward Elgar, Cheltenham, pp. 3-17.

Kroeck, K.G. and Von Glinow, M.A. (2015), "Total rewards in the international context", in Harzing, A.-W. and Pinnington, A.H.(Eds.), International Human Resource Management, Sage, London, pp. 429-467.

Lauring, J. and Selmer, J. (2009), "Expatriate compound living: an ethnographic field study", The International Journal of Human Resource Management, Vol. 20 No. 7, pp. 1451-1467.

Linehan, M. and Scullion, H. (2001), "Challenges for female international managers: evidence from Europe”, Journal of Managerial Psychology, Vol. 16 No. 3, pp. 215-228.

Linehan, M., Scullion, H. and Walsh, J.S. (2001), “Barriers to women's participation in international management”, European Business Review, Vol. 13 No. 1, pp. 10-18.

Linehan, M. and Walsh. J.S. (1999), "Senior female international managers: breaking the glass border”, Women in Management Review, Vol. 14 No. 7, pp. 264-272. 
Mainiero, L.A. and Sullivan, S.E. (2005), "Kaleidoscope careers: an alternate explanation for the "opt-out" revolution", Academy of Management Executive, Vol. 19 No. 1, pp. 106-123.

Mäkelä, L. and Suutari, V. (2011), “Coping with work-family conflicts in the global career context", Thunderbird International Business Review, Vol. 53 No. 3, pp. 365-375.

Mäkelä, L., Känsälä, M. and Suutari, V. (2011), “The roles of expatriates’ spouses among dual career couples", Cross Cultural Management: An International Journal, Vol. 18 No. 2, pp. 185-197.

Markus, U. (2015), Oil and Gas: The Business and Politics of Energy, Palgrave, London.

Mayerhofer, H., Hartmann, L.C. and Herbert, A. (2004), "Career management issues for flexpatriate international staff", Thunderbird International Business Review, Vol. 46 No. 6, pp. 647-666.

Mayerhofer, H., Müller, B. and Schmidt, A. (2010), “Implications of flexpatriates’ lifestyles on HRM practices", Management Revue, Vol. 21 No. 2, pp. 155-173.

McDonnell, A., Collings, D.G., Mellahi, K. and Schuler, R. (2017), “Talent management: a systematic review and future prospects", The International Journal of Human Resource Management, Vol. 11 No. 1, pp. 86-128. 
McNulty, Y. (2014a), "Women as female breadwinners in non-traditional expatriate families: status reversal marriages, single parents, split families, and lesbian partnerships", in Hutchings K. and Michailova, S. (Eds.), Research Handbook on Women in International Management, Edward Elgar, Cheltenham, pp. 332-366.

McNulty, Y. (2014b), "Modern expatriation through the lens of global careers, psychological contracts, and individual return on investment", Global Business and Organizational Excellence, Vol. 33 No. 3, pp. 6-22.

Mendenhall, M.E. and Stahl, G.K. (2000), "Expatriate training and development: where do we go from here?", Human Resource Management, Vol. 39 No. 2/3, pp. 251-266.

Meyskens, M., Von Glinow, M.A., Werther, W.B. and Clarke, L. (2009), “The paradox of international talent: alternative forms of international assignments", The International Journal of Human Resource Management, Vol. 20 No. 6, pp. 1439-1450.

Moore, M.J. (2002), "Same ticket, different trip: supporting dual-career couples on global assignments", Women in Management Review, Vol. 17 No. 2, pp. 61-67.

ORC Worldwide (2007), 2006 Worldwide Survey of International Assignment Policies and Practices, ORC Worldwide, New York, NY.

Orser, B. and Leck, J. (2010), "Gender influences on career success outcomes”, Gender in Management: An International Journal, Vol. 25 No. 5, pp. 386-407. 
Paik, Y. and Vance, C.M. (2002), "Evidence of back-home selection bias against US female expatriates", Women in Management Review, Vol. 17 No. 2, pp. 68-79.

Perkins, S. J., White, G., and Jones, S. (2016), Reward Management: Alternatives, Consequences and Contexts, CIPD, London.

Permits Foundation (2009), International Survey of Expatriate Spouses and Partners: Employment, Work Permits and International Mobility, Permits Foundation, The Hague.

Permits Foundation (2012), International Mobility and Dual Career Survey of International Employers, Permits Foundation, The Hague.

Punnett, B.J., Crocker, O. and Stevens, M.A. (1992), “The challenge for women expatriates and spouses: some empirical evidence", The International Journal of Human Resource Management, Vol. 3 No. 3, pp. 585-592.

Richardson, J., McKenna, S. and Dickie, C. (2014), ““They always look at you a bit oddly”: women developing career capital through international mobility in the mining industry", in Hutchings K. and Michailova, S. (Eds.), Research Handbook on Women in International Management, Edward Elgar, Cheltenham, pp. 367-394.

Rosen, S. (1986), "The theory of equalizing differences”, in Ashenfelter O. and Layard, R. (Eds.), Handbook of Labor Economics, Volume 1, Elsevier Science Publishers B.V., Amsterdam, pp. 641-692. 
Sapsted, D. (2013), “Shale gas: saint or sinner”, Re:Locate, Autumn, pp. 20-22.

Selmer J. and Leung, A.S.M. (2003a), "Provision and adequacy of corporate support to male expatriate spouses: an exploratory study”, Personnel Review, Vol. 32 No. 1, pp. 9-21.

Selmer, J. and Leung, A.S.M. (2003b), "Personal characteristics of female vs male business expatriates", International Journal of Cross Cultural Management, Vol. 3 No. 2, pp. 195212.

Shortland, S. (2009), "Gender diversity in expatriation: evaluating theoretical perspectives", Gender in Management, Vol. 24 No. 5, pp. 365-386.

Shortland, S. (2014a), "Role models: expatriate gender diversity pipeline or pipe-dream?" Career Development International, Vol. 19 No. 5, pp. 572-594.

Shortland, S. (2014b), "Women expatriates: a research history”, in Hutchings K. and Michailova, S. (Eds.), Research Handbook on Women in International Management, Edward Elgar, Cheltenham, pp. 18-44.

Shortland, S. (2015a), “The 'expat factor': the influence of working time on women's decisions to undertake international assignments in the oil and gas industry", The International Journal of Human Resource Management, Vol 26 No. 11, pp. 1542-1473.

Shortland, S. (2015b), "Extreme expatriation: the effect of location factors and masculine environments on women's international assignment participation in oil and gas exploration 
and production", in Connerley, C. and Wu, J. (Eds.), Handbook on Well-Being of Working Women, Springer, New York, pp. 393-411.

Shortland, S. (2016), “The purpose of expatriation: why women undertake international assignments' Human Resource Management, Vol 55 No. 4, pp. 655-678.

Shortland, S. and Altman, Y. (2011), "What do we really know about corporate career women expatriates?", European Journal of International Management, Vol. 5 No. 3, pp. 209234.

Shortland, S. and Cummins, S. (2007), "Work-life balance: expatriates reflect the international dimension”, Global Business and Organizational Excellence, Vol. 26 No. 6, pp. $28-42$.

Shortland, S. and Perkins, S. J. (2016), "Long-term assignment reward (dis)satisfaction outcomes: hearing women's voices”, Journal of Global Mobility, Vol 4 No. 2, pp. 225-250.

Silbiger, A. and Pines, A.M. (2014), "Expatriate stress and burnout”, The International Journal of Human Resource Management, Vol. 25 No. 8, pp. 1170-1183.

Sims, R. H., and Schraeder, M. (2005), "Expatriate compensation: an exploratory review of salient contextual factors and common practices", Career Development International, Vol. 10 No. 2, pp. 98-108. 
Suutari, V., Tornikoski, C. and Mäkelä, L. (2012), "Career decision making of global careerists", The International Journal of Human Resource Management, Vol. 23 No. 16, pp. 3455-3478.

Tharenou, P. (2008), "Disruptive decisions to leave home: gender and family differences in expatriation choices", Organizational Behavior and Human Decision Processes, Vol. 105 No. 2, pp. 183-200.

Tharenou, P. (2009), "Self-initiated international careers: gender differences and career outcomes", in Baugh, S. G. and Sullivan, S. E. (Eds.), Maintaining Focus, Energy, and Options Over the Career, IAP-Information Age Publishing, Charlotte, NC, pp. 197-226.

Tharenou, P. (2010), “Women's self-initiated expatriation as a career option and its ethical issues", Journal of Business Ethics, Vol. 95 No. 1, pp. 73-88.

Tharenou, P. (2014), "Self-initiated expatriation by women: does it help to overcome the glass ceiling?”, in Hutchings K. and Michailova, S. (Eds.), Research Handbook on Women in International Management, Edward Elgar, Cheltenham, pp. 304-331.

Tung, R.L. (2004), “Female expatriates: the model global manager?”, Organizational Dynamics, Vol. 33 No. 3, pp. 243-253.

Tzeng, R. (2006), “Gender issues and family concerns for women with international careers: female expatriates in Western multinational corporations in Taiwan", Women in Management Review, Vol. 21 No. 5, pp. 376-392. 
Varma, A. and Stroh, L.K. (2001), "Different perspectives on selection for international assignments: the impact of LMX and gender", Cross Cultural Management, Vol. 8 No. 3/4, 85-97.

Verma, R. (2008), “At work and play in the 'fishbowl': gender relations and social reproduction among development expatriates in Madagascar", in Coles, A. and Fechter, A.M. (Eds.), Gender and Family among Transnational Professionals, Routledge, London, pp. 171-191.

Welch, D.E., Welch, L.S. and Worm, V. (2007), "The international business traveller: a neglected but strategic human resource", The International Journal of Human Resource Management, Vol. 18 No. 2, pp. 173-183.

Välimäki, S., Lämsä, A-M. and Hiillos, M. (2009), “The spouse of the female manager: role and influence on the woman's career", Gender in Management, Vol. 24 No. 8, pp. 596-614.

Whitson, L. (2013), “Oil's well: meeting the healthcare needs of the energy sector”, Re:Locate, Autumn, p. 23. 